\title{
PENGARUH SUBSTITUSI DAGING KEONG MAS (Pomacea canaliculata L) DAN DAGING AYAM TERHADAP KARAKTERISTIK ORGANOLEPTIK DAN NILAI GIZI NUGGET
}

\section{[The Effect of Golden Apple Snails (Pomacea canaliculata L) and Chicken Meat Substitution on Organoleptic Characteristics and Nutritional Values of Chicken Nuggets]}

\author{
Siti Nurhadia ${ }^{*}$, Hermanto ${ }^{1}$, Suwarjoyowirayatno² \\ 1Jurusan IImu dan Teknologi Pangan, Fakultas Pertanian, Univeristas Halu Oleo. \\ 2Jurusan Teknologi Hasil Perikanan, Fakultas Perikanan dan IImu Kelautan, Univeristas Halu Oleo.
}

*Email: sitinurhadia1996@gmail.com (Telp: +6282239289638)

Diterima tanggal 19 September 2019

Disetujui tanggal 28 Desember 2019

\begin{abstract}
This study aimed to determine the effect of golden apple snail and chicken meat substitution on the organoleptic characteristics and nutritional values of chicken nuggets. This study used a single factor completely randomized design (CRD), with five levels of treatment, namely P0 (0\% golden apple snail meat: $50 \%$ chicken meat: $50 \%$ wheat flour), $P 1$ (45\% golden apple snail meat: $5 \%$ chicken meat: 50\% flour), $P 2$ (40\% golden apple snail meat: $10 \%$ chicken meat: $50 \%$ flour), P3 (35\% golden apple snail meat: $15 \%$ chicken meat: $50 \%$ flour), and P4 (30\% golden apple snail meat: $52 \%$ chicken meat: $50 \%$ flour). Data were analyzed using Analysis of Variance (ANOVA). The results show that the substitution treatment of golden apple snail (Pomacea canaliculata I.) and chicken meat had a very significant effect on increasing color, taste, aroma, and texture. The P1 treatment (45\% golden apple snail meat; $5 \%$ chicken meat and $50 \%$ wheat flour) was the most preferred treatment by panelists with preference scores of color, aroma, texture, and taste reached 3.74 (like), 3.93 (like), 3.68 (like), and 3.68 (like), respectively. Meanwhile, the analysis of the nutritional values shows that the selected treatment contained $30.68 \%$ water, $2.44 \%$ ash, $10.24 \%$ fat, $9.04 \%$ protein, and $47.6 \%$ carbohydrates. Based on the standard of SNI 01-6638-2002, the golden apple snail and chicken meat nuggets met the quality standards on water, ash, and protein contents.
\end{abstract}

Keywords: golden apple snail meat, chicken meat, nuggets.

\section{ABSTRAK}

Penelitian ini bertujuan untuk mengetahui pengaruh subtitusi keong mas dan daging ayam terhadap karakteristik organoleptik dan nilai gizi pada pembuatan nugget. Penelitian ini menggunakan Rancangan Acak lengkap (RAL) faktor tunggal, dengan lima Perlakuan P0 (daging keong mas $0 \%$ : daging ayam $50 \%$ : tepung terigu $50 \%$ ), P1 (daging keong mas $45 \%$ : daging ayam $5 \%$ : tepung terigu $50 \%$ ), P2 (daging keong mas $40 \%$ : daging ayam $10 \%$ : tepung terigu $50 \%$ ), P3 (daging keong mas 35\% : daging ayam 15\% : tepung terigu 50\%) dan P4 (daging keong mas 30\% : daging ayam $52 \%$ : tepung terigu 50\%). Data dianalisis menggunakan Analysis of Varian (ANOVA). Hasil penelitian menunjukkan bahwa perlakuan Substitusi daging keong mas (pomacea canaliculata I.) dan daging ayam berpengaruh sangat nyata terhadap peningkatan warna, rasa, aroma dan tekstur.. Perlakuan P1 (daging keong mas $45 \%$; daging ayam $5 \%$ dan tepung terigu $50 \%$ ) merupakan perlakuan yang paling disukai panelis dengan skor penilaian kesukaan terhadap warna, aroma, tekstur dan rasa berturut-turut sebesar 3,74 (suka), 3,93 (suka), 3,68 (suka), 3,68 (suka), sedangkan berdasarkan analisis nilai gizi meliputi kadar air, abu, lemak, protein dan karbohidrat berturut-turut sebesar $30,68 \%$, $2,44 \%, 10,24 \%, 9,04 \%$ dan 47,6\%. Berdasarkan standar mutu SNI 01-6638-2002 produk nugget daging keong mas dan daging ayam telah memenuhi standar mutu pada kadar air, kadar abu, dan kadar protein. Sedangkan kadar lemak dan kadar karbohidrat belum memenuhi standar mutu SNI 01-6638-2002

Kata kunci: daging keong mas, daging ayam, nugget. 


\section{PENDAHULUAN}

Keong mas (Pomacea canaliculata L.) merupakan salah satu jenis moluska yang sering ditemukan di sawah. Keong mas merupakan hama tanaman padi yang berbahaya karena memakan padi yang baru ditanam dan dapat menghancurkan 50-80\% potensi panen. Menjelang tahun 1988 keong mas dianggap hama padi nomor dua yang paling membahayakan setelah wereng coklat. Keong mas memiliki kemampuan reproduksi yang tinggi, keong mas mudah dapat tumbuh dengan cepat dan hanya memerlukan waktu tiga bulan untuk berkembang biak. Keong mas meletakkan gumpalan telurnya kurang lebih $20 \mathrm{~cm}$ di atas permukaan air, dan setiap gumpalan telur mengandung sekitar 400-700 (Puspita et al., 2005).

Keong mas dapat menyebabkan kerusakan tanaman padi berkisar $10-40 \%$, daerah penyebaran di wilayah Indonesia antara lain Jawa, sulawesi tengara, Sumatra, Kalimantan, NTB dan Bali. Wilayah D.I Yogyakarta daerah penyebarannya di Sleman, Bantul, kota Yogyakarta dan Kulonprogo. Luas serangan yang terjadi di wilayah D.I. Yogyakarta masih sangat rendah tetapi jangka waktu ke depan perlu diwaspadai keberadaan hama keong mas karena perkembangan dan pertumbuhan yang sangat cepat. Keong mas mudah ditemukan di daerah sawah, waduk, situ, rawa dan genangan air (Budiyono, 2006).

Keong mas merupakan hasil perikanan yang kurang ekonomis tetapi dari hasil uji proksimat keong mas memiliki kandungan protein yang cukup tinggi. Salah satu usaha diversifikasi produk berbahan dasar keong mas yaitu dapat dibuat menjadi nugget. Menurut Nursanti (2006) dalam Malayanti (2010), daging keong mas memiliki kandungan protein yang cukup tinggi yaitu sekitar 16\% sampai 18\% dan kandungan lemak yang rendah yaitu sekitar $2,4 \%$.

Produk nugget biasanya menggunakan daging ayam, namun nugget dari daging ikan masih jarang tersedia. Fish nugget adalah salah satu bentuk produk olahan dari daging ikan yang digiling halus dan diberi bumbu-bumbu serta dicampur dengan bahan pengikat dan bahan pengisi, kemudian dicetak menjadi bentuk tertentu setelah itu dikukus, dipotong, dicelupkan ke dalam batter, breading, kemudian digoreng atau disimpan terlebih dahulu dalam ruang pembeku atau freezer sebelum digoreng.

Produk nugget dengan penambahan keong mas ini merupakan produk diversifikasi dengan pemanfaatkan pangan lokal yang dapat menjadi sumber pangan baru yang bergizi dan dapat bermanfaat. Pemanfaatkan potensi lokal, yakni keong mas dikarena mengandung protein yang tinggi, dan juga mampu mengembangkan teknologi pengolahan keong mas dalam bentuk makanan yang banyak digemari anak-anak, seperti nugget dan dapat dijadikan sebagai menu kudapan. 
Berdasarkan uraian diatas, maka dilaporkan hasil penelitian tentang pengaruh substitusi daging keong mas (Pomaceae canaliculata L.) dan daging ayam terhadap karateristik organoleptik dan nilai gizi nugget diharapkan dapat meningkatkan nilai gizi dan memanfaatkan komoditi pangan lokal yang belum maksimal pemanfaatannya.

\section{BAHAN DAN METODE}

\section{Bahan}

Bahan yang digunakan pada penelitian ini antara lain bahan utama adalah keong mas, (Desa Konda, Kabupaten Konawe Selatan), daging ayam dan tepung terigu. Bahan tambahan adalah tepung kanji, susu skim, telur, bawang putih, bawang bombai, merica, garam, tepung panir dan minyak goreng. Bahan kimia

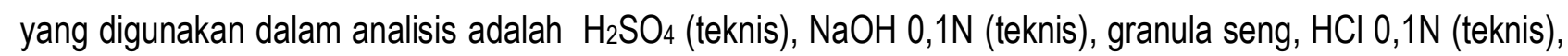
$\mathrm{N}$-heksan, indikator phenolpthalein, $\mathrm{Na}_{2} \mathrm{~S}_{2} \mathrm{O}_{3} 0,1 \mathrm{~N}$ (teknis), $\mathrm{CHCl}_{3}$ (teknis), alkohol 95\%, indikator amilum dan $\mathrm{HCl}$ 9,5N (teknis).

\section{Tahapan Penelitian}

\section{Proses Pembuatan Nugget Keong (Herawati, 2009)}

Keong mas disortasi dan pembersihan kemudian dipisahkan isi dari cangkang dengan menggunakan pisau stainless steel lalu dicuci. Proses pencucian menggunakan air bersih yang mengalir dan air jeruk untuk menghilangkan lendir keong lalu dilakukan pencampuran semua bahan dan bumbu-bumbu dan diaduk hingga rata. Selanjutnya dimasukkan ke dalam cetakan yang sudah diolesi minyak agar adonan tidak lengket dan kemudian dikukus selama 30 menit. Tahap selanjutnya didinginkan kemudian dipotong kecil-kecil. Setelah itu dicelupkan ke dalam kocokan telur 30 gram dan tepung panir 100 gram sebagai pelapis. Tahap terakhir yaitu penggorengan kemudian diangkat dan ditiriskan.

\section{Rancangan Penelitian}

Penelitian ini menggunakan rancangan acak lengkap (RAL) yaitu dengan kosentrasi penambahan daging keong mas P0 (daging keong mas 0\% : daging ayam 50\% : Tepung terigu 50\%), P1 (daging keong mas 45\% : daging ayam $5 \%$ : tepung terigu 50\%), P2 (daging keong mas 40\% : daging ayam $10 \%$ : tepung terigu $50 \%$ ), P3 (daging keong mas 35\% : daging ayam 15\% : tepung terigu 50\%), P4 (daging keong mas 30\% : daging ayam 20\% : tepung terigu 50\%). Masing-masing perlakuan diulang sebanyak 4 kali sehingga diperoleh 20 unit percobaan. Rancangan ini berdasarkan hasil penelitian pendahuluan. 


\section{Variabel Pengamatan}

Pengamatan pada penelitian ini yaitu uji organoleptik diantaranya warna, aroma, tekstur, dan rasa untuk mengetahui tingkat kesukaan panelis. Panelis terdiri 30 orang panelis tidak terlatih. Setelah itu dilanjutkan dengan analisis proksimat nugget dari perlakuan terbaik yang diperoleh dari uji organoleptik terdiri dari analisis kadar air metode termogravimetri (AOAC, 2005), kadar abu metode termogravimetri (AOAC, 2005), kadar protein metode Kjedahl (AOAC, 2005), kadar lemak metode ekstraksi dengan alat Soxhlet (AOAC, 2005) dan karbohidrat yang dihitung berdasarkan metode by difference (Winarno, 2004).

\section{Analisis Data}

Data dianalisis dengan menggunakan sidik ragam ANOVA (Analysis of Varian), Hasil analisis data yang diperoleh berpengaruh nyata terhadap variabel pengamatan, dilanjutkan dengan uji Duncan's multiple range test (DMRT) pada taraf kepercayaan $95 \%(a=0,05)$.

\section{HASIL DAN PEMBAHASAN}

\section{Penilaian Uji Organoleptik}

Hasil rekapitulasi analisis sidik ragam pengaruh substitusi daging keong mas dan daging ayam terhadap karakteristik organoleptik nugget terhadap karakteristik organoleptik meliputi warna, aroma, tekstur dan rasa nugget disajikan pada Tabel 1.

Tabel 1. Rekapitulasi hasil analisis sidik ragam uji hedonik nugget substitusi daging keong mas (Pomaceae canaliculata) dan daging ayam

\begin{tabular}{ccc}
\hline No & Variabel pengamatan & Analisis Sidik Ragam \\
\hline 1 & Warna & $* *$ \\
2 & Aroma & $* *$ \\
3 & Rasa & $* *$ \\
4 & Tekstur & $* *$ \\
\hline
\end{tabular}

Keterangan: ${ }^{* *}=$ Berpengaruh sangat nyata pada taraf signifikan 0,05

Berdasarkan data Tabel 1, menunjukkan bahwa perlakuan penggunaan substitusi daging keong mas dan daging ayam terhadap karakteristik organoleptik nugget berpengaruh sangat nyata terhadap karakteristik organoleptik warna, tekstur, aroma dan rasa produk nugget. 
Warna

Pengujian organoleptik pada nugget dari hasil pengaruh substitusi daging keong mas dan daging ayam terhadap karakteristik organoleptik nugget menunjukkan penilaian warna berpengaruh sangat nyata. Sehingga dilanjutkan dengan uji DMRT pada taraf kepercayaan 95\% ( $\alpha=0,05)$. Penilaian kesukaan warna nugget disajikan pada Tabel 2.

Tabel 2. Rerata hasil penilaian organoleptik warna nugget dengan substitusi daging keong mas (Pomaceae canaliculata) dan daging ayam

\begin{tabular}{cccc}
\hline Simbol & $\begin{array}{c}\text { Formulasi } \\
(\text { KM }: \text { DA : TT })(\%)\end{array}$ & $\begin{array}{c}\text { Rerata Organoleptik } \\
\text { Warna }\end{array}$ & Kategori \\
\hline P0 & $(0: 50: 50)$ & $3,28^{\mathrm{b}} \pm 0,84$ & Agak Suka \\
P1 & $(45: 5: 50)$ & $4,39^{\mathrm{a}} \pm 0,73$ & Suka \\
P2 & $(40: 10: 50)$ & $3,37^{\mathrm{b}} \pm 0,82$ & Agak suka \\
P3 & $(35: 15: 50)$ & $3,21^{\mathrm{b}} \pm 0,80$ & Agak suka \\
P4 & $(30: 20: 50)$ & $2,87^{\circ} \pm 0,88$ & Agak suka \\
\hline Keterangan & $:$ Angka-angka yang & diikuti oleh huruf yang berbeda menunjukkan beda nyata berdasarkan u \\
& DMRT 0,05 Keong mas (KM), Daging ayam (DA), dan Tepung terigu (TT) &
\end{tabular}

Berdasarkan data Tabel 2, menunjukkan bahwa rerata penilaian warna yang tertinggi terdapat pada perlakuan P1 dengan nilai sebesar 4,39 (suka) sedangkan yang terendah terdapat pada perlakuan P4 dengan nilai sebesar 2,87 (agak suka). Hal ini diduga karena konsentrasi substitusi daging keong mas 45\% dan daging ayam 5\% pada perlakuan P1 akan membuat produk nugget yang dihasilkan berwarna kecoklatan, sehingga semakin banyak penambahan daging keong mas pada nugget maka warna yang dihasilkan semakin disukai panelis. Hal ini sesuai penelitian Permadi et al., (2011) yang menyatakan bahwa dalam pembuatan nugget dengan subtitusi daging ayam yang mengandung pigmen mioglobin yang berwarna kekuningan dapat mempengaruhi warna nugget. Hal ini sejalan dengan penelitian Miftakhurohmah (2011), yang menyatakan bahwa seiring dengan meningkatnya penambahan daging tutut maka warna nugget yang dihasilkan semakin cokelat.

\section{Aroma}

Pengujian organoleptik pada nugget dari hasil pengaruh substitusi daging keong mas dan daging ayam terhadap karakteristik organoleptik nugget menunjukan penilaian aroma berpengaruh sangat nyata. Penilaian kesukaan aroma nugget disajikan pada Tabel 3. 
Tabel 3. Rerata hasil penilaian organoleptik aroma nugget dengan substitusi daging keong mas (Pomaceae canaliculata) dan daging ayam

\begin{tabular}{cccc}
\hline Simbol & $\begin{array}{c}\text { Formulasi } \\
(\text { KM }: \text { DA :TT })(\%)\end{array}$ & $\begin{array}{c}\text { Rerata Organoleptik } \\
\text { Aroma }\end{array}$ & Kategori \\
\hline P0 & $(0: 50: 50)$ & $3,35^{\mathrm{b}} \pm 0,87$ & Agak Suka \\
P1 & $(45: 5: 50)$ & $4,23^{\mathrm{a}} \pm 0,70$ & Suka \\
P2 & $(40: 10: 50)$ & $3,39^{\mathrm{b}} \pm 0,95$ & Agak suka \\
P3 & $(35: 15: 50)$ & $3,05^{\mathrm{b}} \pm 0,97$ & Agak suka \\
P4 & $(30: 20: 50)$ & $2,94^{\mathrm{c}} \pm 0,98$ & Agak suka
\end{tabular}

Keterangan : Angka-angka yang diikuti oleh huruf yang berbeda menunjukkan beda nyata berdasarkan uji DMRT 0,05 Keong mas (KM), Daging ayam (DA), dan Tepung terigu (TT)

Berdasarkan data Tabel 3, menunjukkan bahwa rerata penilaian aroma yang tertinggi terdapat pada perlakuan P1 dengan nilai sebesar 4,23 (suka) sedangkan yang terendah terdapat pada perlakuan P4 dengan nilai sebesar 2,94 (agak suka). Hal ini diduga karena adanya penambahan keong mas 45\%, dimana semakin banyak penambahan keong mas maka aroma nugget yang dihasilkan semakin tercium. Hal ini yang dapat mempengaruhi tingkat penerimaan panelis. Sesuai dengan hasil penelitian Oktasari (2014), dalam pembuatan nugget dengan penambahan keong sawah 20\%, hal ini dikarenakan semakin banyak penambahan keong sawah maka aroma khas daging keong sawah yang dihasilkan semakin disukai oleh panelis.

\section{Tekstur}

Pengujian organoleptik pada nugget dari hasil pengaruh substitusi daging keong mas dan daging ayam terhadap karakteristik organoleptik nugget menunjukkan penilaian tekstur berpengaruh nyata. Penilaian kesukaan tekstur nugget disajikan pada Tabel 4.

Tabel 4. Rerata hasil penilaian organoleptik tekstur nugget substitusi daging keong mas (Pomaceae canaliculata) dan daging ayam

\begin{tabular}{cccc}
\hline & Formulasi & Rerata Organoleptik & Kategori \\
Simbol & $($ KM : DA :TT $)(\%)$ & Tekstur & \\
\hline P0 & $(0: 50: 50)$ & $3,40^{\mathrm{b}} \pm 0,98$ & Agak Suka \\
P1 & $(45: 5: 50)$ & $4,29^{\mathrm{a}} \pm 0,99$ & Suka \\
P2 & $(40: 10: 50)$ & $3,18^{\mathrm{bc}} \pm 0,96$ & Agak suka \\
P3 & $(35: 15: 50)$ & $2,98^{\mathrm{cd}} \pm 0,95$ & Agak suka \\
P4 & $(30: 20: 50)$ & $2,86^{\mathrm{c}} \pm 0,07$ & Agak suka \\
\hline
\end{tabular}

Keterangan : Angka-angka yang diikuti oleh huruf yang berbeda menunjukkan beda nyata berdasarkan uji DMRT 0,05 Keong mas (KM), Daging ayam (DA), dan Tepung terigu (TT)

Berdasarkan data Tabel 4, menunjukkan bahwa rerata penilaian tekstur yang tertinggi terdapat pada perlakuan P1 dengan nilai sebesar 4,29 (suka) sedangkan yang terendah terdapat pada perlakuan P4 dengan 
nilai sebesar 2,86 (agak suka). Perlakuan P1 memiliki tekstur nugget yang agak kenyal, sehingga semakin banyak penambahan daging keong mas pada pembuatan produk nugget maka tekstur yang dihasilkan semakin disukai oleh panelis. Hal ini didukung oleh hasil penelitian Listiana dan Isworo (2012), dalam pembuatan nugget menyatakan bahwa panelis lebih menyukai nugget keong sawah dengan tekstur agak kenyal, dikarenakan perbandingan kosentrasi penambahan pati temu iren lebih sedikit dari daging keong sawah sehingga tekstur nugget yang dihasilan agak kenyal.

\section{Rasa}

Pengujian organoleptik pada nugget dari hasil pengaruh substitusi daging keong mas dan daging ayam terhadap karakteristik organoleptik nugget menunjukkan penilaian rasa berpengaruh sangat nyata, penilaian kesukaan rasa nugget disajikan pada Tabel 5.

Tabel 5. Rerata hasil penilaian organoleptik rasa nugget substitusi daging keong mas (Pomaceae canaliculata) dan daging ayam

\begin{tabular}{cccc}
\hline Simbol & $\begin{array}{c}\text { Formulasi } \\
(\text { KM : DA : TT })(\%)\end{array}$ & Rerata Organoleptik & Kategori \\
\hline P0 & $(0: 50: 50)$ & $3,25^{\mathrm{b}} \pm 0,98$ & Agak Suka \\
P1 & $(45: 5: 50)$ & $4,51^{\mathrm{a}} \pm 0,76$ & Suka \\
P2 & $(40: 10: 50)$ & $3,11^{\mathrm{b}} \pm 0,88$ & Agak suka \\
P3 & $(35: 15: 50)$ & $3,06^{\mathrm{b}} \pm 0,86$ & Agak suka \\
P4 & $(30: 20: 50)$ & $2,79^{\mathrm{c}} \pm 0,94$ & Agak suka \\
\hline
\end{tabular}

Keterangan : Angka-angka yang diikuti oleh huruf yang berbeda menunjukkan beda nyata berdasarkan uji DMRT 0,05. Keong mas (KM), Daging ayam (DA), dan Tepung terigu (TT)

Berdasarkan data Tabel 5, menunjukkan bahwa rerata penilaian rasa yang tertinggi terdapat pada perlakuan P1 dengan nilai sebesar 4,51 (suka) sedangkan yang terendah terdapat pada perlakuan P4 dengan nilai sebesar 2,79 (agak suka), hal ini diduga karena sedikitnya penambahan daging keong mas sehingga bisa menurunkan rata-rata penerimaan panelis, sedangkan pada perlakuan P1 disukai panelis karena semakin banyak penambahan daging keong mas maka rasanya lebih gurih. Hal ini sesuai dengan hasil penelitian Junardi dan syahrul (2015), yang menyatakan adanya perlakuan dengan penambahan daging keong sawah dapat mempengaruhi daya terima konsumen dikarenakan semakin banyak penambahan keong sawah semakin terasa. Hal ini didukung oleh hasil penelitian Susanti (2017), yang mengatakan bahwa pada nugget dengan penambahan keong sawah $40 \%$ didapatkan rasa yang lebih enak dengan kombinasi rasa gurih.

\section{Analisis Nilai Gizi}

Analisis nilai gizi kandungan nugget terpilih meliputi, kadar air, abu, lemak, protein dan karbohidrat disajikan pada Tabel 6. 
Tabel 6. Rekapitulasi perbandingan perlakuan terbaik dan kontrol analisis nilai gizi nugget

\begin{tabular}{clccc}
\hline & & \multicolumn{2}{c}{ Perlakuan } & \\
\cline { 3 - 4 } No & Variabel Pengamatan (\%) & Kontrol & Terpilih & SNI \% \\
& & PO & P1 & \\
\hline 1 & Kadar Air & $31,60 \pm 0,85$ & $30,68 \pm 0,74$ & Maks. 60 \\
2 & Kadar Abu & $1,89 \pm 0,36$ & $2,44 \pm 0,78$ & Mak. 3 \\
3 & Kadar Lemak & $11,19 \pm 0,17$ & $10,24 \pm 0,23$ & Min. 12 \\
4 & Kadar Protein & $12,19 \pm 0,84$ & $9,04 \pm 0,82$ & Maks. 20 \\
5 & Kadar Karbohidrat & 43,13 & 47,6 & Maks. 25 \\
\hline
\end{tabular}

Keterangan : $\mathrm{P0}=(\mathrm{KM}: \mathrm{DA}: \mathrm{TT})(\%):(0: 50: 50) ; \quad \mathrm{P} 1=(\mathrm{KM}: \mathrm{DA}: \mathrm{TT})(\%):(45: 5: 50)$. Keong mas $(\mathrm{KM})$, Daging ayam (DA), dan Tepung terigu (TT)

\section{Kadar Air}

Berdasarkan data pada Tabel 6, menunjukkan bahwa kadar air pada nugget diperoleh perlakuan tertinggi yaitu pada kontrol P0 dengan kadar air sebesar 31,60\% Sedangkan kadar air pada perlakuan P1 dengan kadar air sebesar 30,68\% yang sudah memenuhi standar SNI 01-2973 1992 yaitu maksimal 60\% baik kontrol maupun perlakuan. Perlakuan P1 lebih rendah dibandingkan dengan kadar air kontrol karena penggunaan keong mas begitu efektif pada pembuatan nugget. Hal ini sesuai dengan hasil penelitian Listiana dan Isworo (2012), yang menyatakan bahwa dalam pembuatan nugget keong sawah memiliki kandungan kadar air sebesar 15,30\%. Hal ini sesuai dengan hasil penelitian Ageng et al., (2013) perbedaan kadar air bahan pada pembuatan nugget ayam juga dapat mempengaruhi kadar air yang dihasilkan karena kadar air daging ayam rata-rata adalah $75,30 \%$.

\section{Kadar Abu}

Berdasarkan data pada Tabel 6, menunjukkan bahwa kadar abu pada nugget diperoleh perlakuan tertinggi yaitu pada perlakuan P1 dengan kadar abu sebesar 2,44\%. kadar abu terendah yaitu pada kontrol P0 dengan kadar abu sebesar 1,89\% yang sudah memenuhi standar SNI 01-2973 1992 yaitu maksimal 3\% baik kontrol maupun perlakuan. Tingginya kadar abu pada perlakuan P1 diduga karena kandungan kadar abu yang ada pada bahan baku seperti kalsium, fosfor dan besi. Hal ini sesuai dengan pendapat Persagi (2009) yang menyatakan bahwa dalam 100 gram daging keong tutut mengandung kalsium $217 \mathrm{mg} / 100 \mathrm{gram}$, fosfor $78 \mathrm{mg} / 100 \mathrm{gram}$ dan besi $1,7 \mathrm{mg} / 100$ gram, sedangkan ayam mengandung kalsium $14 \mathrm{mg} / 100$ gram, fosfor $200 \mathrm{mg} / 100 \mathrm{gram}$ dan besi $1,5 \mathrm{mg} / 100 \mathrm{gram}$. Selain berasal dari bahan baku, kadar abu berasal dari bahan tambahan seperti bahan pengisi dan bahan pengikat. 


\section{Kadar Lemak}

Berdasarkan data pada Tabel 6, menunjukkan bahwa kadar lemak tertinggi terdapat pada kontrol P0 dengan kadar lemak sebesar 11,19\% sedangkan yang terendah terdapat pada perlakuan P1 dengan kadar lemak sebesar $10,24 \%$. Hal ini dinyatakan bahwa pada perlakuan P1 dan P0 telah memenuhi syarat mutu SNI 01-2973 1992 nugget dengan minimal kadar lemak pada nugget yaitu 12\%. Rendahnya kadar lemak pada perlakuan P1 diduga karena adanya penggunaan keong sawah dimana kadar lemak yang terkandung pada keong sawah yaitu 0,70\%-0,99\%, sedangkan pada perlakuan P0 kadar lemak yang terkandung pada daging ayam yaitu 20\%-25\%. Hal ini sesuai dengan hasil penelitian Yuliana et al., (2013) dalam pembuatan nugget dengan mensubstitusi daging ayam menghasilkan kadar lemak sebesar 12,92\%. Hasil penelitian Listiana dan Isworo (2012), dalam pembuatan nugget dengan mensubstitusi keong sawah menghasilkan kadar lemak sebesar $14,03 \%$. Meningkatnya kadar lemak nugget keong sawah juga disebabkan oleh proses penggorengan. Pada proses penggorengan nugget terjadi perpindahan panas dan massa, panas akan menguapkan air dan kemudian bahan akan menyerap minyak atau lemak, sehingga kadar lemak dalam nugget meningkat (Sasikumar, 2005).

\section{Kadar Protein}

Berdasarkan data pada Tabel 12, menunjukkan bahwa kadar protein tertinggi terdapat pada kontrol P0 dengan nilai sebesar $12,19 \%$ sedangkan yang terendah terdapat pada perlakuan P1 dengan nilai sebesar $9,04 \%$, hal ini dikarenakan kandungan protein dari daging ayam yang cukup tinggi dibandingkan dengan keong mas. Hal ini sesuai dengan hasil penelitian Widyastuti et al. (2010) yang menyatakan bahwa dalam pembuatan nugget daging ayam memiliki kandungan protein sebesar 20,13\% sedangkan keong mas memiliki kandungan protein sebesar 15,58 \% (Liptan, 2001 dalam Apriyanti et al., 2016). Hal ini sesuai penelitian Ishak et al., (2014) yang menyatakan bahwa dikarenakan dengan adanya proses penyimpanan dan proses penggorengan yang terlalu lama sehingga kadar protein yang ada pada nugget ayam tidak mencapai kisaran yang diinginkan. Oleh karena itu kandungan protein antara nugget kontrol dan nugget terpilih berbeda secara signifikan.

\section{Kadar Karbohidrat}

Berdasarkan data pada Tabel 15, menunjukkan bahwa kadar karbohidrat tertinggi terdapat pada perlakuan $\mathrm{P} 1$ (daging keong mas $45 \%$ daging ayam 5\% tepung terigu 50\%) dengan nilai sebesar 47,6\% sedangkan kadar protein pada perlakuan P0 (daging ayam 50\% dan tepung terigu 50\%) dengan nilai sebesar $43,13 \%$. Kadar karbohidrat pada penelitian tidak memenuhi standar yang telah ditentukan oleh SNI No. 012973-1992 yaitu maksimal 25\%. Menurut Sugito dan Hayati (2006), kadar karbohidrat yang dihitung secara 
By difference dipengaruhi oleh komponen nutrisi lain, semakin rendah komponen nutrisi lain maka kadar karbohidrat akan semakin tinggi. Begitu juga sebaliknya semakin tinggi komponen nutrisi lain maka kadar karbohidrat akan semakin rendah. Akan tetapi, walaupun jumlah maksimal dan minimal dari komponen gizii dihitung menurut SNI 01-2973-1992. Namun, Komponen nutrisi yang bisa mempengaruhi besarnya kandungan karbohidrat diantaranya adalah kandungan protein, lemak, air dan abu.

\section{KESIMPULAN}

Terdapat pengaruh sangat nyata subtitusi keong mas terhadap pembuatan nugget pada penilaian karakteristik organoleptik warna, aroma, dan rasa nugget. Namun tidak berpengaruh nyata terhadap karakteristik organoleptik tekstur nugget. Pengaruh subtitusi keong mas terhadap nilai gizi pembuatan nugget yaitu pada perlakuan P1 (daging keong mas $45 \%$ daging ayam $5 \%$ dan tepung terigu $50 \%$ ) dengan kadar air sebesar 30,68\%, kadar abu sebesar 1,89\%, kadar lemak sebesar 10,24\%, kadar protein sebesar 9,04\%, kadar karbohidrat sebesar $47,6 \%$

\section{DAFTAR PUSTAKA}

Apriyanti., Nurfaika A, Bauzir E, Choiriyah U dan Dinastian ON. 2016. Analisis potensi keong mas sebagai substitusi daging sapi dalam pembuatan nugget sebagai makanan olahan kaya protein. Jurnal RISENOLOGI KPM UNJ. 1 (1) : 2502-5643.

Ageng MP, Rosyidi D dan Widyastuti ES. 2013. Pengaruh penambahan pati biji durian terhadap kualitas kimia dan organoleptik nugget ayam. Jurnal IImu-IImu Peternakan. 23 (3): $17-26$.

AOAC. 2005. Official Methods Of Analysis. Washington DC. US.

Budiyono S. 2006. Teknik Mengendalikan Keong Mas pada Tanaman Padi. Jurnal-jurnal Ilmu Pertanian. 2 (2) : 26-28.

Herawati P. 2009. Karakteristik Nugget keong mas (Pomacea canaliculata) Dengan Penambahan Karagenan dan Tepung Tapioka. Skripsi. Fakultas Teknologi Pertanian. Institut Pertanian Bogor.

Ishak M, Saleh EJ dan Rachman AB. 2014. Karakteristik kadar protein, lemak, dan karbohidrat nugget ayam yang terbuat dari tepung ubi hutan (Dioscorea hispida dennst). Jurnal IImiah Agrobisnis Tropis. 7 (3): $120-124$.

Junardi, Ilza M, dan Syahrul. 2015. Studi penerimaan konsumen terhadap Nugget ikan lele dumbo (Clarias gariepinus), keong sawah (Pilaampullacea) dan kombinasinya. JOM. Edisi Oktober : 1-8.

Listiana T dan Isworo JT. 2012. sifat fisik, kimia dan organoleptik nugget keong sawah dengan bahan pengisi pati temu ireng. Jurnal Pangan dan Gizi. 3 (5) : 23-24. 
Malayanti. 2010. Karakteristik saus keong mas (Pomacea canaliculata) dengan penambahan buah nanas sebagai sumber enzim bromelin. Skripsi. Fakultas Pertanian, Universitas Sriwijaya. Palembang

Miftakhurohmah. 2011. Pengaruh Subsitusi Keong Tutut (Bellamnya javanica) Terhadap Mutu Fisikokimia dan Organoleptik Nugget Tinggi Kalsium dan Sumber Protein. Skripsi. Departemen Gizi Masyarakat, Fakultas Ekologi Manusia Institut Pertanian Bogor. Bogor.

Oktasari N. 2014. Pemanfaatan Keong Sawah (Pila Apucallacea) Pada Pembuatan Nugget Sebagai Alternative Makanan Berprotein Tinggi Di Desa Jurug Kecamatan Mojosongo Kabupaten Boyolali. Skripsi. Universitas Negri Semarang.

Permadi SN, Mulyani S dan Hintono A. 2011. Kadar Serat, Sifat Organoleptik, dan Rendemen Nugget Ayam Yang Disubstitusi Dengan Jamur Tiram Putih (Plerotus Ostreatus) Jurnal Aplikasi Teknologi Pangan. $1(4): 117-118$.

Persagi Persatuan Ahli Gizi. 2009. Tabel Komposisi Pangan Indonesia: Elex Media Komputindo. Jakarta.

Puspita L., Ratnawati INN, Suryadiputra A, dan Meutia A. 2005. Lahan Basah Buatan di Indonesia. Wetlands International Indonesia Program. 3(2): 64-67.

Sasikumar B. 2005. Genetic Resources of Curcuma : Diversity, Characterization and Utilization. India : Indian Institute of Spices Research, Calicut 673 012, Kerala.

Hayati S. 2006. Penambahan daging ikan gabus dan aplikasi pembekuan pada pembuatan pempek gluten. Jskripsi. Fakultas Pertanian. Universitas Sriwijaya. Sumatera Selatan.

Susanti R. 2017. Pengaruh penambahan keong sawah terhadap mutu organoleptik nugget. Politeknik kesehatan Kemenkes Padang. Padang.

Widyastuti ES., Aris SW, Rery DH dan Made YA. 2010. Kualitas Nugget dengan Penambahan Daging Ayam. Jurnal IImu dan Teknologi Hasil Ternak, Universitas Brawijaya. 5 (1) : 1-10.

Winarno FG. 2004. Kimia pangan dan gizi. edisi ke sebelas. Gramedia pustaka utama. Jakarta.

Yuliana N., Yoyok B, Pramono dan Hintono A. 2013. Kadar Lemak, Kekenyalan dan Cita Rasa Nugget Ayam Yang Disubstitusi dengan Daging Ayam Broiler. Jurnal Peternakan Hewan. 2 (1) : 1-8. 